\title{
Torlesse, Waipapa and Caples suspect terranes of New Zealand: Integrated studies of their geolo- gical history in relation to neighbouring terranes
}

1 Institute of Geological \& Nuclear Sciences, P. O. Box 31312, Lower Hutt, New Zealand.

2 Institute of Geological \& Nuclear Sciences, Private Bag, Dunedin, New Zealand

The Pacific margin of eastern Gondwanaland comprises a major Paleozoic-Mesozoic mobile belt at the edge of the Australian-Antarctic Precambrian craton. Recent studies provide new insight into the provenance and locus of sediment depocentres at this margin and their subsequent movement to become major New Zealand suspect terranes (Torlesse, Waipapa and Caples Terranes) prior to Early Cretaceous amalgamation.

\section{Introduction}

New Zealand originated as part of a Paleozoic-Mesozoic mobile belt at the Gondwanaland margin adjacent to the Australian-Antarctic Precambrian Craton (Suggate, 1978; Korsch \& Wellman, 1988). With the recognition of several tectono-stratigraphic terranes within New Zealand (Figure 1), their autochthonous/allochthonous relationships, assembly and present configuration in terms of plate kinematic models (e.g. Coombs et al., 1976; Bishop et al., 1985; Bradshaw, 1989) have been much debated. We review here paleontological, petrographic, geochemical, geochronological and isotopic data that contribute to this debate, with special reference to the PermianCretaceous Torlesse, Waipapa and Caples sedimentary terranes of eastern New Zealand.

\section{Late Paleozoic setting at the Australasian margin of Gondwanaland}

Two Paleozoic fold-belts are present at the eastern Gondwanaland margin: (i) the Cambrian-Ordovician, Ross-Delamerian Orogen (Transantarctic Mountains-South Australia), with mostly S-type (but also I-type) granitoid complexes in Proterozoic sediments (Figure 2) and to the east (ii) the Lachlan Fold Belt (eastern, mostly southeastern Australia) comprising Devonian-Early Carboniferous, I- and Stype granitoid complexes in Cambrian-Ordovician sedimentary terranes. Analogues of the latter extend southward to southern New Zealand, the Campbell Plateau, Marie Byrd Land, West Antarctica and North Victoria Land, East Antarctica (Adams, 1981; Vetter et al., 1982; Figure 2). In N.E Australia, the northern Lachlan and Thomson Fold Belts contain mainly Ordovician-Silurian (but some Silurian-Devonian) S-type granitoids in similar Paleozoic (Anakie Inlier and Hodgkinson Province) sedimentary terranes and Proterozoic metamorphic complexes of N. E. Queensland (Figure 2). These eastern fold-belts signify a major convergent plate margin environment, especially in S. E. Australia, New Zealand and adjacent parts of Antarctica, from Silurian to mid-Carboniferous times. Oblique subduction then commenced in the Carboniferous in the northern sector (N.E. Queensland) and Permian-Triassic in the central sector (Queensland-New South Wales), generating the extensive I- and Stype granitoid terranes of the New England Orogen. From the Early Jurassic, there was a change to a passive-margin environment. In total, the Australasian-Antarctic continental borderland thus shows considerable Paleozoic geological diversity (Figure 2), which should also be reflected in later, Permian-Cretaceous, sedimentary basins developed nearby.

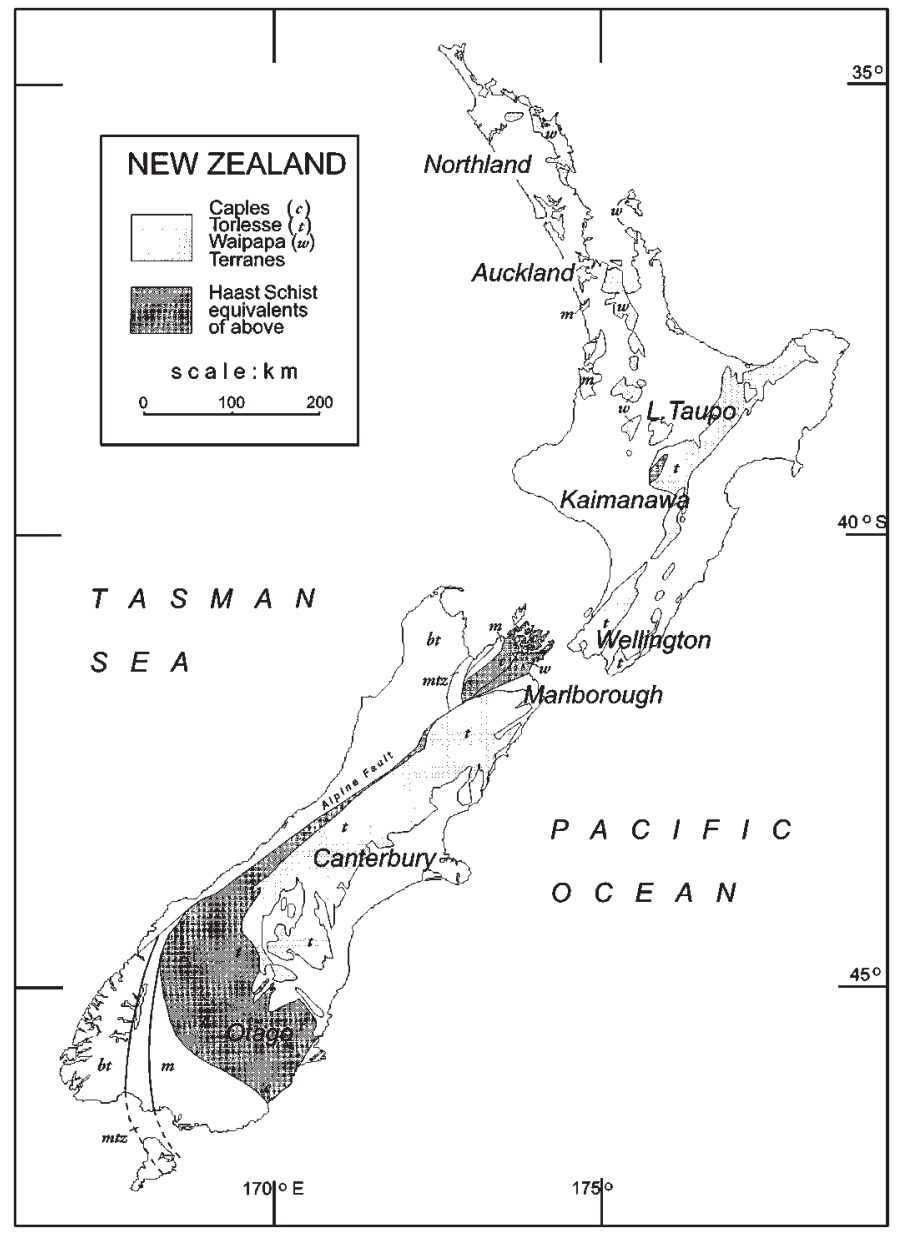

Figure 1 Main areas of New Zealand Permian-Jurassic sediments and schist equivalents, in relation to the Buller and Takaka Terranes (bt) of the Gondwana foreland.

Abbreviations: $c$-Caples; mtz-Median Tectonic Zone; m-Central Arc - Terranes (Brook Street, Dun Mountain-Maitai, Murihiku); - Torlesse; w-Waipapa. 


\section{New Zealand late Paleozoic-Mesozoic tectono-stratigraphic terranes}

The Permian-Cretaceous geology of New Zealand is best described (Figure 1) in terms of several Eastern Province, tectono-stratigraphic terranes (Bishop et al., 1985). These are separated from the Western Province, Buller and Takaka Terranes (Paleozoic) by a Median Tectonic Zone (MTZ), a zone of Triassic-Cretaceous (mainly) plutonic rocks (Bradshaw, 1993; Kimbrough et al., 1994). The Eastern Province comprises an eastern terrane group (from east to west, Torlesse, Waipapa and Caples) which are greywacke-dominated turbidite sequences (Suggate, 1978). The easternmost, Torlesse Terrane, sediments are the most quartzose, whilst the Waipapa and Caples Terranes are more volcaniclastic (MacKinnon, 1983). A central arc terrane group (from east to west, Dun Mountain-Maitai, Murihiku and Brook Street) intervenes between the MTZ and this eastern group; the easternmost, Maitai Terrane includes quartzose sediments but the others include basic to intermediate volcanics and volcaniclastic sediments (MacKinnon, 1983).

All these terranes are probably $>1,000 \mathrm{~km}$ in length but $<150$ $\mathrm{km}$ in width. With the exception of the Murihiku Terrane, Late Permian-Early Triassic and Late Triassic-Early Jurassic (Rangitata Orogeny Phase I) deformation/metamorphism have obliterated good stratigraphic sections. Furthermore, later Late Jurassic-Early Cretaceous (Rangitata Orogeny Phase II) tectonism has internally imbricated and truncated the terranes (Suggate, 1978; Bradshaw et al., 1981). Particularly in the Torlesse Terrane, these factors place an increased reliance on regional characterisation of terrane sediments; using their metamorphic history, fossil biotas, petrofacies and geochemical, age and isotopic signatures, to identify provenance.

\section{Metamorphic geochronology of the Eastern Province of New Zealand}

Our geochronological studies have concentrated heavily in the Rakaia Subterrane of the Torlesse Terrane, parts of the adjacent Waipapa Terrane and their Haast Schist equivalents (including some parts of the Caples Terrane; Figure 1). K-Ar age patterns reflect postmetamorphic (Rangitata Orogeny, Phase I) uplift and cooling, from latest Triassic to Middle Cretaceous times (200 to $120 \mathrm{Ma}$ ). With the exception of some Permian Torlesse Terrane rocks, there are dramatic maximum and minimum K-Ar age limits at 210-215 and 140145 Ma (Adams \& Robinson, 1993; Adams \& Graham, 1996; Adams et al., 1998, in preparation), the younger limit being accentuated by local thermal events associated with late imbrication tectonism.

$\mathrm{Rb}-\mathrm{Sr}$ whole-rock isochron ages date: (1) a Late Permian to Early Triassic metamorphism in Permian sectors of the Rakaia Subterrane in Canterbury and (2) a more widespread (certainly Otago to Wellington) regional metamorphism (Rangitata Orogeny, Phase I) throughout the Rakaia Subterrane, in latest Triassic to earliest Jurassic times, 200-210 Ma, (Graham \& Korsch, 1989; Adams \& Graham, 1996, 1997) and (3) a more local Early Cretaceous (120-140 Ma) metamorphism associated with Rangitata Orogeny Phase II, (Mortimer, 1993a,b) In the Rakaia Subterrane this often occurs in local ductile shear (imbrication) zones (Adams \& Graham, 1996). The $\mathrm{Rb}-\mathrm{Sr}$ age studies suggest a continuum from burial metamorphism to deformation and regional metamorphism, followed by back-rotation, uplift and cooling from west to east, from older to younger, sectors of the accretionary prism (Suneson, 1993). The main accretionary phases are Late Permian, Middle to Late Triassic and Late Jurassic to Early Cretaceous.

Timing of amalgamation of the eastern and central arc terrane groups is still uncertain. The $\mathrm{K}-\mathrm{Ar}$ metamorphic age pattern in the
Dun Mountain Terrane is similar to that in Torlesse Terrane (Harper \& Landis, 1967; Coombs et al., 1976).

The structure of the Murihiku Terrane is dramatically simpler, with a semi-continuous succession from Early Triassic to Late Jurassic in the Southland and Kawhia Synclines but there is evidence for tectonism in the Early to Middle Jurassic and Late Jurassic to Early Cretaceous.

\section{Fossil biotas, faunal realms and terrane origins}

The original fossil database for the Torlesse, Caples and Waipapa Terranes (Campbell \& Warren, 1965; Speden, 1976) was largely based on macrofossil collections. This has steadily enlarged in recent years, but notably with collection of productive microfossil localities: radiolarians (Aita \& Sporli, 1992), fusuline foraminifers (Leven \& Grant-Mackie, 1997: Leven \& Campbell, 1998), calcispheres (Campbell \& Handler, 1996), conodonts (Ford, 1995) and dinoflagellates (Wilson et al., 1988). The key to this progress has been largely due to recognition and systematic sampling of potentially fossiliferous lithologies: limestones, phosphoritic and calcareous

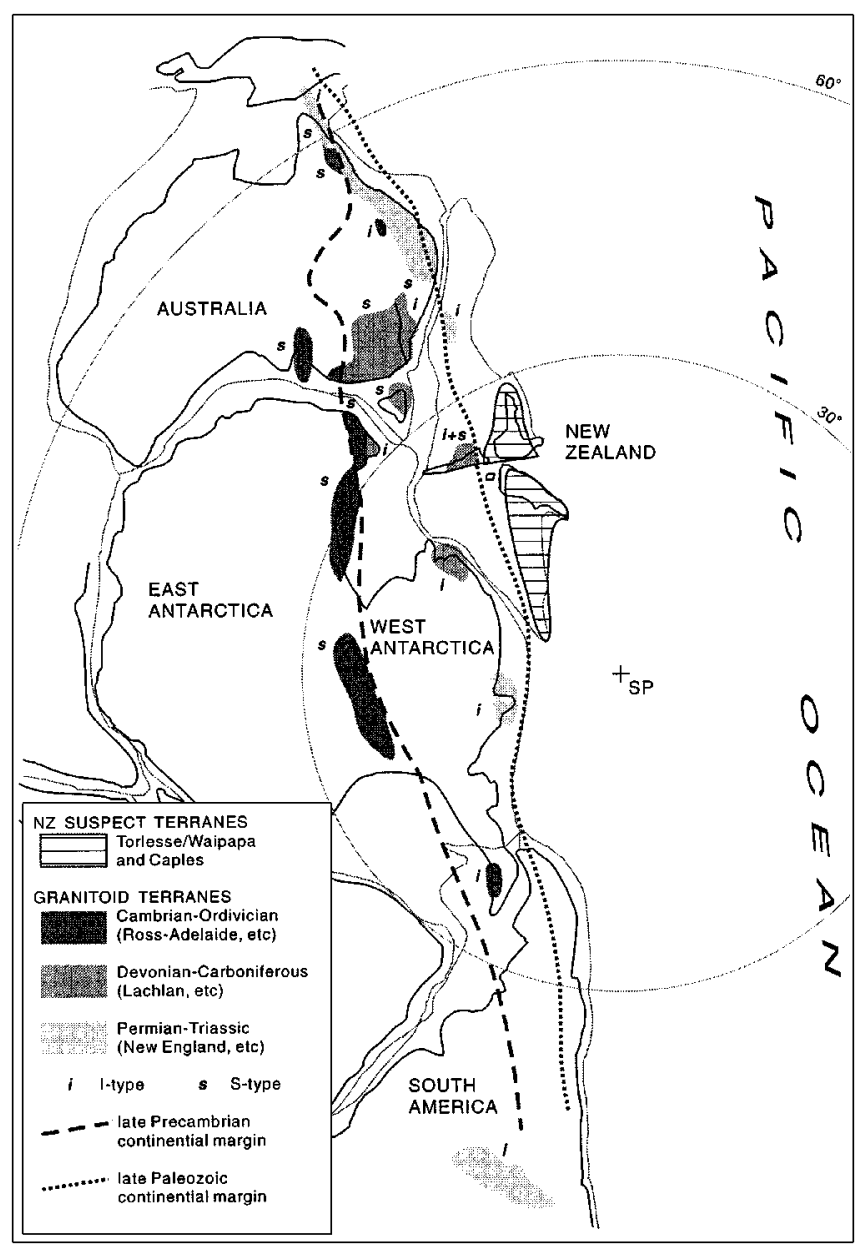

Figure 2 Late Triassic (210 Ma) configuration of eastern Gondwanaland (after Powell \& Li, 1994; with small Antarctic modifications after DiVenere et al., 1994) showing the margin at Late Precambrian (c.600 Ma) and Late Carboniferous (c.300 $\mathrm{Ma}$ ), as dashed and dotted lines respectively and between them, the main I- and S-type Paleozoic granitoid terranes. The apparent position of the eastern terranes (Torlesse, Waipapa and Caples) of New Zealand is shown in relation to these (Their distortion probably results from imprecise estimation and removal of post-Cretaceous deformation). 

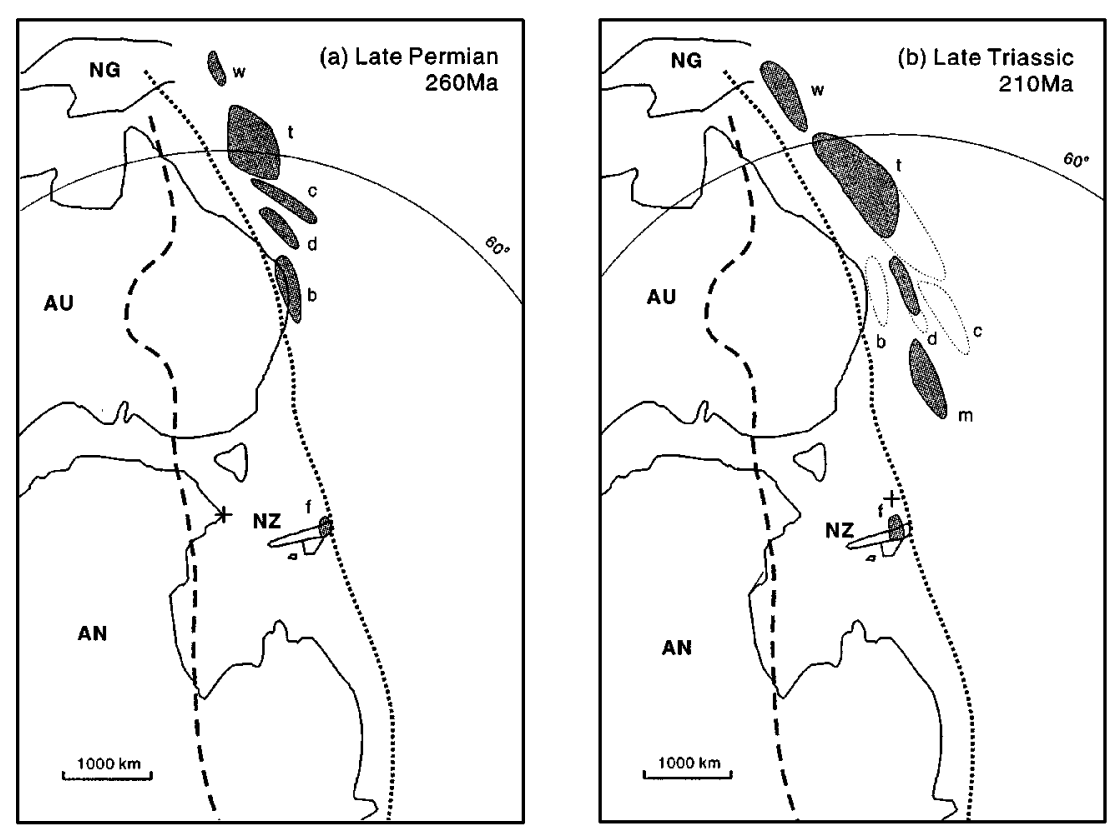

nodules, hemipelagites and cherts. This breakthrough has lead to much more precision in stratigraphic age control for sequences within these terranes.

The new data support the dual character of typical accretionary margin subduction complexes for all three terranes: a predominantly clastic wedge with a distinctive fauna that is characterised by elements of a Gondwanaland margin affinity that can be referred to the Austrazean Province and a minor but also very distinctive biogenic sedimentary component that relates to off-scraped oceanic plate sequences, complete with guyots, that have been introduced tectonically by sea floor spreading. As a rule, but not always, the oceanic sequences reflect warmer oceanic and climatic conditions of Tethyan affinity and older ages than the clastic sequences (Hornibrook \& Shu, 1965; Hada \& Landis, 1995). This makes sense in terms of the subduction-accretion model with consumption of old sea floor proximal to a riverine continental mass with high relief.

Analysis of fossil content within clastic sequences in the Torlesse Terrane continues to indicate that there were a number of major episodes of sedimentation: Late Permian, Middle to Late Triassic and Late Jurassic to Early Cretaceous. No Early Triassic or Early-Middle Jurassic fossils have yet been recognized (Campbell et al., 1993).
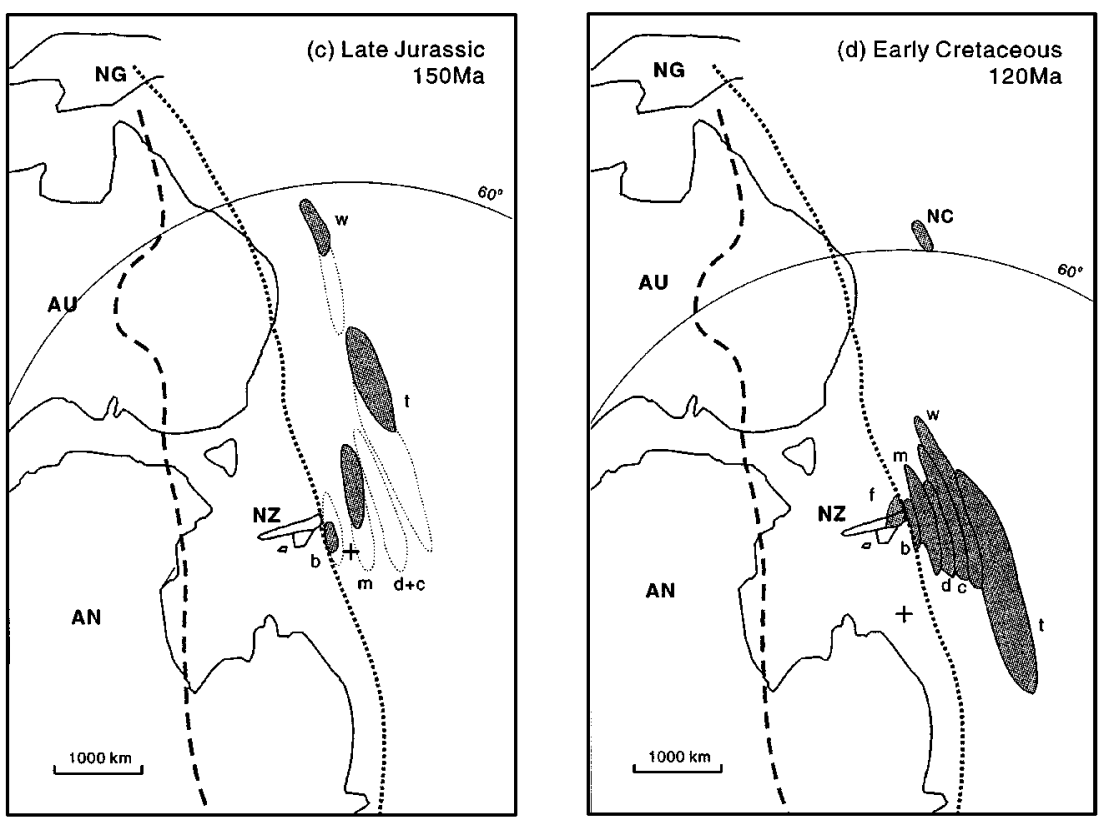

In terms of paleobiogeography, the fossil biotas of clastic sequences within Torlesse, Caples and Waipapa Terranes are entirely compatible with original depositional sites proximal to the Eastern Australian margin of Gondwanaland. In Figure 3 we attempt to summarize the history of these depocentres and their subsequent incorporation into terranes. Whilst recognizing many gaps in our knowledge and some contradictions in points of detail, we feel this provides an important starting point for discussion. For example, fossil analysis of oceanic sequences within each of these terranes has thrown some light on relative location of each terrane depocentre with respect to the paleo-Pacific oceanic plate: Waipapa Terrane Late Permian and Middle Triassic faunas appear to reflect a more Tethyan affinity than either Torlesse or Caples Terrane. The Caples rocks show the coldest aspect of the three and are therefore regarded as the most southerly in station.

Figure 3 The eastern margin of Gondwana showing a suggested location of New Zealand tectono-sedimentary basins at (a) Late Permian, $260 \mathrm{Ma}$; (b) Late Triassic, $210 \mathrm{Ma}$; (c) Late Jurassic, $150 \mathrm{Ma}$. In (d), their configuration is shown as terranes at midCretaceous, $120 \mathrm{Ma}$. The size and shape of terrane envelopes indicates their relative volumes in space and time. Their amalgamation largely occurred between $150 \mathrm{Ma}$ and $120 \mathrm{Ma}$.

Terrane name abbreviations: $b$-Brook Street; $c$-Caples; $d-$ Dun Mountain-Maitai; $m$-Murihiku; $t$-Torlesse; $w$ - Waipapa; $f-$ Western Province cover sediments of Parapara Group (Permian) and Topfer Formation (Triassic).

Dashed and heavy dotted lines denote Gondwana margin in Late Precambrian (c.600 Ma) and Late Carboniferous (c.300 Ma) respectively. South Poles (+) and $60^{\circ} \mathrm{S}$ paleolatitudes are from Powell \& Li (1994) and C.A. Powell (1998 personal communication). Fine dotted lines around basin envelopes denote the extent of their earlier components. AN-Antarctica; AU-Australia; NC-New Caledonia; NG - New Guinea; NZ - New Zealand.

\section{Tectonic setting from petro-} graphic and geochemical petrofacies

Petrographic framework modes of Eastern Province greywackes have been used to define regional petrofacies (e.g. MacKinnon, 1983; Mortimer, 1995). These petrographic data are further underpinned by geochemical data, including analysis of schistose rocks (e.g. Mortimer \& Roser, 1992; Roser et al., 1993). Consistent compositional differences are demonstrated between South Island terranes; Torlesse sandstones are volcaniclastic and plutoniclastic with $68-72$ wt $\% \mathrm{SiO}_{2}$ but Caples sandstones are volcaniclastic with lithic grains of basalt and andesite. Subtle differences in Q:F:L and Lv/L exist between Torlesse sandstones of different age (MacKinnon, 1983). In the North Island, sandstones of the Waipapa Terrane of Spörli (1978) seem to overlap Caples and Torlesse data in both age and composition (Mortimer, 1995). Therefore the compositional and paleogeographic status of the Waipapa Terrane still remains to be fully resolved. The petrofacies approach has also provided some of the earliest source area models for the Eastern Province terranes, 
MacKinnon (1983) proposing an Antarctic source for the Torlesse (see below).

\section{Provenance constraints from strontium isotopes and detrital minerals}

The Rb-Sr isochron studies on the Torlesse, Waipapa and Caples Terrane sediments yield age (t) and initial ${ }^{87} \mathrm{Sr} /{ }^{86} \mathrm{Sr}$ ratios at the time of metamorphism (i) effectively constituting isotopic signatures and constraining minimum (t), maximum (i) and bulk $\mathrm{Rb} / \mathrm{Sr}$ values for their source. In this way, Torlesse, Waipapa and Caples protoliths can be traced into Haast Schist (Graham \& Mortimer, 1992; Adams \& Graham, 1997; Adams et al., 1998). Similarly, one can deduce that the calc-alkaline granitoid source of the Rakaia sediments is dominated by I-types: (t) $>230 \mathrm{Ma}$, (i) $<0.7065, \mathrm{Rb} / \mathrm{Sr} \mathrm{c} .0 .8$, with only a minor contribution from more radiogenic, (i) $>0.708$, country rocks or S-type granites (Adams, 1997). The age patterns of detrital zircons and muscovites tend to confirm this: the major age component being Permian-Triassic, 230-270 Ma (both), with minor components at 420-440 Ma (muscovite) and 500-550 Ma (zircon) derived from schists and acid volcanics respectively (Ireland 1992; Adams \& Kelley, 1998).

\section{Putting it together: a provenance for the eastern suspect terranes}

The size of the eastern terrane group and the Torlesse Terrane in particular, about $2000 \mathrm{~km}$ long, $200 \mathrm{~km}$ broad and 5-10 km deep, requires a source terrane of comparable magnitude, for example, a long convergent-margin orogenic belt. The extensive, southern Lachlan Fold Belt of S.E. Australia (including Antarctic continuations) and the adjacent Ross/Delamerian Orogen, contains major components of the appropriate size and petrographic composition i.e. granitoids, schists etc., but are an unlikely source because (i) they have characteristic K-Ar mineral cooling age peaks at 350-400 Ma and 460-500 Ma, which are dramatically absent from the Torlesse detrital mineral Ar-Ar age populations and (ii) their granitoids are mainly S-type, (i) >0.708 (Chappell \& White, 1974). A more likely source area is the Carboniferous-Triassic, New England Fold-Belt of N.E. Australia; a convergent plate margin with extensive Permian calcalkaline, I-type granitoids and associated arc volcanism providing Torlesse (Rakaia) source materials in the correct proportions (Adams, 1996; Adams \& Kelley, 1998; Figure 2).

One cannot entirely exclude a distant easterly provenance however (MacKinnon, 1983), in eastern Marie Byrd Land, Antarctic Peninsula or even southern South America, where there are small isolated outcrops of Permian (and Carboniferous) igneous and Early Paleozoic metamorphic rocks over a very large area (Milne \& Millar 1991; Cingolani et al., 1991; Pankhurst et al., 1993; Figure 2). It is difficult to estimate how well these rocks represent the geology beneath the West Antarctic Ice-Sheet or southern Patagonia Cenozoic.

\section{New insights into New Zealand terrane identities}

The integration of petrographic and isotopic data has lead to a refinement of our understanding of the New Zealand Eastern Province terranes and highlighted some shortcomings in their high level nomenclature in terms of terrane and subterranes. In particular it seems that the Waipapa Terrane lacks integrity; Torlesse-like rocks occur within it and Waipapa-like rocks occur outside it. As suggested by
Black (1994; 1996), it is perhaps better regarded as three entities, in part Caples Terrane, in part Torlesse Terrane (Pahau) and the remainder considered as a new separate unit (Bay of Islands Terrane). Similarly, there are Torlesse-like rocks within the present confines of the Caples and Torlesse Terranes that would seem to belong in such a new terrane. The new data clearly permit a critical review of the existing terranes and are leading to a revision of their terrane/subterrane status

\section{A Circum-Pacific view of major terrane movements}

The evolution of the Pacific Plate (at the expense of the Phoenix Plate) at the Gondwanaland margin is seen as a diachronous transition from convergent to extensional tectonics; starting in an equatorial position north of Australia in the Early Jurassic, moving along the New Zealand and West Antarctic sectors during the Cretaceous and continuing to the Antarctic Peninsula (where the Phoenix Plate is now almost consumed) during the Cenozoic. The general kinematics require some margin parallel, transform faults (Bradshaw, 1989; Rowley et al., 1991) and possibly commensurate oblique movement of older (pre-Cretaceous) accreted metasediment and volcanic terranes along this margin. It is envisaged that this mechanism generates the New Zealand suspect terranes; their progressive anticlockwise displacement, with respect to the Gondwanaland margin (Figure 3), in total about 2000km, is accumulated over 80-100 million years $(200-120 \mathrm{Ma})$ at rates $(20-25 \mathrm{~mm} / \mathrm{yr})$ similar to known Cenozoic plate motion in the South Pacific region.

\section{Hidden marginal terranes in the South Pacific?}

If the Paleozoic margin of N.E. Australia is the starting point for New Zealand eastern terrane depocentres, this raises the question of analogous depocentres in the NZ-Antarctic sector. These late Paleozoic to early Mesozoic sediments (e.g. offshore of ' $f$ ' in Figure 3) would be similar to the Torlesse but more radiogenic, (i) $>0.708$ and have only 'Lachlan' and 'Ross-Delamerian' detrital mineral age patterns. Sediments of this age or type have not been found in the New Zealand region but there are large areas of the Campbell Plateau where the pre-Cretaceous basement is uncertain. However, such rocks could now be suspect terranes, displaced in the same sense as the Torlesse and now situated in the Antarctic Peninsula to South America sector (Figure 3). (Note Jurassic dextral terrane displacements in West Antarctica suggested by Rowley et al. (1991)). Some possible candidates could be Cretaceous(?)-Jurassic, LeMay Formation, Alexander Island (Laudon, 1991); Triassic-Jurassic, Trinity Peninsula Formation, Antarctic Peninsula; Triassic, Miers Bluff Formation, South Shetland Islands (Hervé et al., 1991) and Permian-Triassic fore-arc of southern Chile (Forsythe, 1982). Some detrital zircon (Hervé et al. 1991) and preliminary Rb-Sr (t)-(i) data (Davidson et al., 1987; Willans et al., 1994) for these support such a model but crucial ${ }^{40} \mathrm{Ar} /{ }^{39} \mathrm{Ar}$ muscovite and U-Pb SHRIMP zircon detrital mineral ages and $\mathrm{Rb}-\mathrm{Sr}(\mathrm{t})-(\mathrm{i})$ data are lacking.

\section{Acknowledgements}

This work has formed part of a major research programme 'Origin of the New Zealand Continental Crust' and predecessors, 1988-1998, funded in part by the New Zealand Public Good Science Fund 19911998. 


\section{References}

Adams, C.J., 1981, Geochronological correlations of Precambrian and Paleozoic orogens in New Zealand, Marie Byrd Land (West Antarctica), Northern Victoria Land (East Antarctica), Northern Victoria Land (East Antarctica) and Tasmania, in Cresswell M.M. and Vella, P., eds, Gondwana Five: Balkema, Rotterdam, pp. 191-192.

Adams, C.J., 1996, A Queensland provenance for New Zealand Permo-Triassic Torlesse metagreywacke terranes: A review of the age and isotopic evidence, in Mesozoic Geology of the Eastern Australia Plate Conference, Brisbane, Australia: Geological Society of Australia Inc., Extended Abstracts No.43, pp. 1-6.

Adams, C.J., 1997, Tracing the continuity and ancestry of Paleozoic and Mesozoic metasedimentary terranes at the southwest Pacific margin of Gondwana by their age and strontium isotope characteristics, in Bradshaw, J.D. and Weaver, S.D., eds, Terrane Dynamics 97, University of Canterbury, Christchurch, N.Z., pp. 1-4.

Adams, C.J. and Robinson, P., 1993, Potassium-argon age studies of metamorphism/uplift/cooling in Haast Schist coastal sections south of Dunedin, Otago, New Zealand: New Zealand Journal of Geology and Geophysics, v. 36, pp. 317-325.

Adams, C.J. and Graham, I.J., 1996, Metamorphic and tectonic geochronology of the Torlesse Terrane, Wellington, New Zealand: New Zealand Journal of Geology and Geophysics, v. 3, pp. 157-180.

Adams, C.J. and Graham, I.J., 1997, Age of metamorphism of Otago Schist in eastern Otago and determination of protoliths from initial strontium isotope characteristics: New Zealand Journal of Geology and Geophysics, v.40, pp. 275-286

Adams, C.J. and Kelley, S., 1998, Provenance of Permo-Triassic and Ordovician metagreywacke terranes in New Zealand: evidence from $40 \mathrm{Ar}$ 139Ar dating of detrital micas: Geological Society of America Bulletin, v. 110, pp. 422-432.

Adams, C.J.; Graham, I.J. and Johnston, M.R., 1998 (in press), Age and isotopic characterisation of geological terranes in Marlborough Schist, Nelson/Marlborough, New Zealand: New Zealand Journal of Geology and Geophysics (accepted for publication).

Aita, Y. and Spörli, K.B., 1992, Tectonic and paleobiogeographic significance of radiolarian microfaunas in the Permian to Mesozoic basement rocks of the North Island, New Zealand: Palaeogeography, Palaeoclimatology, Palaeoecology, v. 96, pp. 103-125.

Bishop, D.G.; Bradshaw, J.D and Landis, C.A., 1985, Provisional terrane map of South Island, New Zealand, in Howell, D.G., ed, Tectonostratigraphic Terranes: Circum-Pacific Council for Energy and Mineral Resources Earth Science Series No. 1, Houston, Texas, pp. 515-521.

Black, P.M., 1994, The "Waipapa Terrane", North Island, New Zealand: Subdivision and correlation:. Geoscience Reports of Shizuoka University, v. 20, pp. 55-62.

Black, P., 1996, Omahuta, Bay of Islands and Manaia Hill Terranes: Waipapa Composite Terrane, North Island, NZ, in Morrison, M.; Landis, C.; Tulloch, A., eds, Geological Society of New Zealand 1996 Annual Conference, 26-28 November, University of Otago, Dunedin: Programmes and Abstracts, p. 29

Bradshaw, J.D., 1989, Cretaceous geotectonic patterns in the New Zealand region: Tectonics, v. 8, pp. 803-820.

Bradshaw, J.D., 1993, A review of the Median Tectonic Zone: terrane boundaries and terrane amalgamation near the Median Tectonic Line: New Zealand Journal of Geology and Geophysics, v. 36, pp. 117-125.

Bradshaw, J.D., Andrews, P.B. and Adams, C.J., 1981, Carboniferous to Cretaceous on the Pacific margin of Gondwana: The Rangitata Phase of New Zealand, in Cresswell, M.M.; Vella, P., eds, Gondwana Five: Papers and abstracts of papers presented at the Fifth International Gondwana Symposium, Balkema, Rotterdam, pp. 217-221.

Campbell, J.D. and Warren, G., 1965, Fossil localities of the Torlesse Group in the South Island, Transactions of the Royal Society of New Zealand, v. 3 , pp. $99-137$.

Campbell, H.J. and Handler, M., 1992, Upper Jurassic fauna from limestone at Mukamuka (Wairarapa) and its significance. Geological Society of New Zealand Miscellaneous Publication 63A, p.43.

Campbell, H.J., Grapes, R. and Simes, J.E., 1993, Time sliced: the Jurassic corridor in the Torlesse. Geological Society of New Zealand Miscellaneous Publication 79A, p. 49

Campbell, H.J. and Simes, J.E., 1996, Torlesse Fossils. In Begg, J.G.; Mazengarb, C. Geology of the Wellington area: Institute of Geological and Nuclear Sciences Geological Map 21

Cingolani, C., Dalla Salda, L., Herve, F., Munizaga, F., Pankhurst, R.J., Parada, M.A. and Rapela, C.W., 1991, in Harmon, R.S., Rapela, C.W., eds, Andean Magmatism and its Tectonic Setting: Geological Society of America Special Paper 265, pp. 29-44.

Chappell, B.W. and White, A.J.R., 1974, Two contrasting granite types: Pacific Geology, v. 8, pp. 173-174.

Coombs, D.S., Landis, C.A., Norris, R.J., Sinton, J.M., Borns, D.J. and Craw, D., 1976, The origin of the Dun Mountain Ophiolite Belt, New Zealand, its tectonic setting, constitution, and, with special reference to the southern portion: American Journal of Science, v. 276, pp. 561-603.

Davidson, J., Mpodozis, C., Godoy, E., Hervé, F., Pankhurst and R.J., Brook, 1987, Late Paleozoic accretionary complexes along the Gondwana margin of southern Chile: Evidence from the Chonos Archipelago, in McKenzie, G.D., ed, Gondwana Six: Structure, Tectonics and Geophysics. Geophysical Monograph 40: American Geophysical Union, Washington, pp. 221-228.

DiVenere, V.J., Kent, D.V. and Dalziel, I.W.D., 1994, Mid-Cretaceous Paleomagnetic results from Marie Byrd land, West Antarctica: A test of post100Ma relative motion between East and West Antarctica: Journal of Geophysical Research, v. 99, p. 15115-15139.

Ford, P., 1995, Permian conodonts from Torlesse and Caples Terranes, South Island, New Zealand, in Worthington, T.J. and O'Connor, B.M., eds, 1995 Annual Conference, 22-24 November, University of Auckland, Auckland: Programme and Abstracts, Geological Society of New Zealand Miscellaneous Publication 81A, p.108.

Forsythe, R.D., 1982, The late Paleozoic to early Mesozoic evolution of southern south America: a plate tectonic interpretation: Quarterly Journal of the Geological Society of London, v. 139, pp. 671-682.

Graham, I.J. and Korsch, R.J., 1989, Rb-Sr resetting ages and chemical characterization of turbidites in an accretionary wedge, Torlesse Complex, Otaki Gorge, New Zealand: Geological Society of America Bulletin, v. 101 , pp. 355-363.

Graham, I.J. and Mortimer, N.M., 1992, Terrane characterisation and timing of metamorphism in the Otago Schist, New Zealand using Rb-Sr and KAr geochronology: New Zealand Journal of Geology and Geophysics, v. 35, pp. 391-401.

Hada, S. and Landis, C.A., 1995, Te Akatarawa Formation - an exotic oceanic-continental margin terrane within the Torlesse-Haast Schist transition zone: New Zealand Journal of Geology and Geophysics, v. 38, pp. 349-359.

Harper, C.T. and Landis, C.A., 1967, K-Ar ages from regionally metamorphosed rocks, South island, New Zealand, and some tectonic implications: Earth and Planetary Science Letters, v. 2, pp. 419-429.

Hervé, F., Loske, W., Miller, H. and Pankhurst, R.J., 1991, Chronology of provenance, deposition and metamorphism of deformed fore-arc sequences, southern Scotia arc. In Thomson, M.R.A., Crame, J.A. and Thomson, J.W., eds, Geological Evolution of Antarctica: Cambridge University Press, Cambridge, pp. 429-435.

Hornibrook, N. de B. and Shu, Y.K., 1965, Fusuline limestones in the Torlesse Group near Benmore Dam, Waitaki Valley. In Campbell, J.D.; Warren, G., Fossil localities of the Torlesse Group in the South Island: Transactions of the Royal Society of New Zealand , Geology, v. 3, pp. 99-137

Ireland, T.R., 1992, Crustal evolution of New Zealand: Evidence from age distributions of detrital zircons in Western Province paragneisses and Torlesse greywacke: Geochimica et Cosmochimica Acta, v. 56, pp. 911-920.

Kimbrough, D.L., Tulloch, A.J., Coombs, D.S., Landis, C.A., Johnston, M.R. and Mattinson, J.M., 1994, Uranium-lead zircon ages from the Median Tectonic Zone, South Island, New Zealand: New Zealand Journal of Geology and Geophysics, v. 37, pp. 393-419.

Korsch, R.J. and Wellman, H.W., 1988, The Geological Evolution of New Zealand and the New Zealand region, in: Nairn, A.E.M.; Stehli, F.C., Uyeda, S., eds, The ocean basins and margins, volume 7, The Pacific Ocean; Plenum, New York, pp. 411-482.

Laudon, T.S., 1991, Petrology of sedimentary rocks from the English Coast, Eastern Ellsworth Land. In Thomson, M.R.A., Crame, J.A. and Thomson, J.W., eds, Geological Evolution of Antarctica: Cambridge University Press, Cambridge, pp. 455-460.

Leven, EJ and Grant-Mackie, J.A., 1997, Permian fusulinid Foraminifera from Wherowhero Point, Northland, New Zealand: New Zealand Journal of Geology and Geophysics, v. 40, pp. 473-486.

Leven, E.J. and Campbell, H.J., 1998, Middle permian (Murgabian) fusuline faunas, Torlesse Terrane, New Zealand: New Zealand Journal of Geology and Geophysics, v. 41, pp. 149-156.

MacKinnon, T.C., 1983, Origin of the Torlesse terrane and coeval rocks, South Island, New Zealand: Geological Society of American Bulletin, v. 94, pp. 967-985.

Milne, A.J. and Millar, I.L., 1991, Mid-Palaeozoic basement in Eastern Graham Land and its relation to the Pacific margin of Gondwana. in Thom- 
son, M.R.A., Crame, J.A. and Thomson, J.W., eds, Geological Evolution of Antarctica: Cambridge University Press, Cambridge, pp. 335-340

Mortimer, N., 1993a, Jurassic tectonic history of the Otago Schist, New Zealand: Tectonics, v. 12, pp. 237-244.

Mortimer, N., 1993b, Geology of Otago Schist and adjacent rocks. Scale 1: 500000 Institute of Geological and Nuclear Sciences Geological Map 7 (1 Sheet). IGNS Lower Hutt, New Zealand.

Mortimer, N., 1995, Origin of the Torlesse Terrane and coeval rocks, North Island, New Zealand. International Geology Review, v. 30, pp. 891-910.

Mortimer, N. and Roser, B.P., 1992, Geochemical study of the Caples and Torlesse boundary in the Otago Schist, New Zealand: Journal of the Geological Society of London, v. 149, pp. 967-977.

Powell, C.McA. and Li, Z.X., 1994, Reconstruction of the Panthalassan margin of Gondwanaland. In Veevers, J.J. and Powell, C. McA., eds, Permian-Triassic Pangean basins and foldbelts along the Panthalassan margin of Gondwanaland: Geological Society of America Memoir 184, pp. 5-9.

Roser, B.P., Grapes, R.H. and Palmer, K., 1993, Petrofacies and subterrane affiliation of Torlesse sediments, southern North Island, New Zealand: Geological Society of New Zealand Miscellaneous Publication 79A, p. 130.

Rowley, P.D., Kellogg, K.S., Vennum,W.R., Laudon, T.S., Thomson, J.W., O'Neill, and J.M, Lidke, D.J., 1991, Tectonic setting setting of the English Coast, Eastern Ellsworth Land, Antarctica, in Thomson, M.R.A., Crame, J.A. and Thomson, J.W., eds, Geological Evolution of Antarctica: Cambridge University Press, Cambridge, pp. 467-473.

Speden, I.G., 1976, Fossil localities in Torlesse Rocks of the North Island, New Zealand: Journal of the Royal Society of New Zealand, v. 6, pp. 73-91.

Spörli, K.B., 1978, Mesozoic tectonics, North Island, New Zealand: Geological Society of America Bulletin, v. 89, pp. 415-425.

Suggate, R.P. (Chief Editor), 1978, The Geology of New Zealand. Government Printer, Wellington (2 volumes), $343 \mathrm{pp}$

Suneson, N.H., 1993, The geology of the Torlesse Complex along the Wellington area coast, North Island, New Zealand: New Zealand Journal of Geology and Geophysics, v. 36, pp. 369-384.

Vetter, U., Roland, N.W., Kreuzer, H., Höhndorf, A., Lenz, H. and Besang, C., 1982, Geochemistry, petrography, and geochronology of the Cambro-Ordovician and Devonian-Carboniferous granitoids of Northern Victoria Land, Antarctica, in Oliver, R.L., James, P.R. and Jago, J.B., eds, Antarctic Earth Science, Australian Academy of Science, Canberra, pp. 140-143.

Willans, R.C.R., Pankhurst, R.J.and Hervé, F., 1994, A probable Early Triassic age for the Miers Bluff Formation, Livingston Island, South Shetland Islands: Antarctic Science, v. 6, pp. 401-408

Wilson, G.J.; Moore, P.R. and Isaac, M.J., 1988, Age of the greywacke basement in the Urewera Ranges, eastern North Island, New Zealand: New Zealand Geological Survey Record 35, pp. 29-33.
Chris Adams is a geochronologist at the Institute of Geological and Nuclear Sciences, Lower Hutt, New Zealand. His main interest is in the regional application of $\mathrm{Ar}-\mathrm{Ar}, \mathrm{Rb}-\mathrm{Sr}$, $U-P b$ dating methosds to the identification, ancestry and assembly of circum-Pacific terranes and tectonic-metamorphic controls of their mineral resources.

Hamish Campbell is a geologist st the Institute of Geological and Nuclear Sciences, Lower Hutt, New Zealand. He has specialist knowledge of Permian-Triassic marine invertebrate faunas of eastern Gondwanaland. Currently he is involved in solving chronostratigraphic and biogeographic problems relating to the original sedimentary depocentres of exotic terranes in the southwest Pacific.

Ian Graham is a senior scientist at the Institute of Geological \& Nuclear Sciences, Lower Hutt, New Zealand, where he currently heads geochronological and isotope geochemical research projects, particularly related to cosmogenic isotopic dating applications in Quaternary Cenozoic sediments and mineralisation studies in Mesozoic-Cenozoic environments.

Nick Mortimer is a petrologiststructural geologist at the Institute of Geological and Nuclear Sciences, Dunedin, New Zealand. He works on a diversity of interdisciplinary onshore and offshore geological projects, most of which address the origin, growth and disruption of New Zealand in both Gondwana and circum-Pacific contexts.
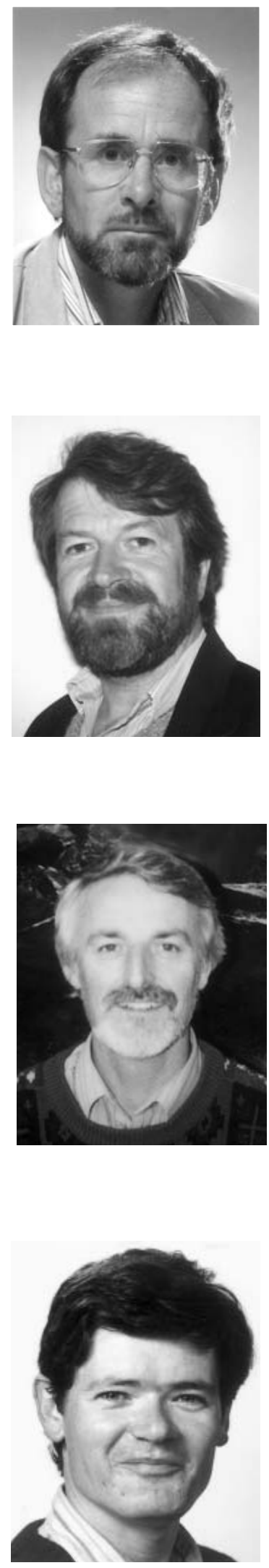